\section{Grand plans for global changes}

Ottawa

THE International Council of Scientific Unions (ICSU) last week approved in principle a major international interdisciplinary research programme on interactions of the geosphere and the biosphere. The aim of the programme is to understand global change over long timescales, and in particular the influence of man on the environment.

Advocates of the venture, to be called the International Geosphere Biosphere Program (IGBP), argue that instruments now becoming available should be used in a coordinated fashion to monitor environmental changes that might affect human civilization as the Earth's population increases. Specific proposals are so far lacking; but the fate of carbon in the ocean and the long-term effects of high-yield agriculture on soils are likely to figure prominently.

But despite the laudable sentiments expressed last week by those seeking to avert possible environmental disaster, many were critical of what they saw as woolly thinking. Professor Tom Malone of the US National Academy of Sciences, a prominent champion of IGBP, promoted J. E. Lovelock's "Gaia" superorganism concept of the global environment, an idea most biologists find untenable. Speaker after speaker at a day-long symposium at last week's ICSU meeting emphasized the inter-relatedness of various facets of the geosphere and biosphere without specifying what new studies were needed.

Interestingly, some of the reactions heard last week may reflect the different styles of science in Europe and North America. One summary talk that featured a slide of starving children was privately criticized by some European delegates for using cheap tactics, while being praised for its effectiveness by American scientists. The second group argued that the purpose of the symposium was to stir delegates to action rather than to advance understanding.

The British Royal Society has been the leading the opposition to IGBP, believing that unless it was more carefully focused, the project could divert attention, and possibly resources, from existing international studies such as the World Climate Research Program. Some of the ideas canvassed for IGBP last week were nothing if not ambitious, with up to 50 dedicated Earth satellites being proposed. A compromise put forward by Academician V.V. Belousov of the Soviet Union and agreed by the general assembly calls for an ad hoc committee to work out specific proposals for IGBP in time for the next ICSU general assembly in 2 years' time. Sir Arnold Burgen, foreign affairs secretary of the Royal Society, said he was "'quite happy"' with Belousov's formula.
Everybody stresses that the programme is unlikely to produce data before the $1990 \mathrm{~s}$, and that the sort of long-term data acquisition needed will require a shift of attitudes from short-term fashionable projects towards more methodical data collection. But the success of International Geophysical Year in the late 1950s is being held up as an example of what might be achieved.

Tim Beardsley

\section{Visas denied}

THE Ottawa meeting of ICSU was marred by angry exchanges and protests by the Soviet delegation at the denial of entry visas to two Soviet representatives. A statement by the Canadian Ministry of External Affairs read out at the meeting said the government had ensured visas for "all bona fide scientists" to facilitate free association.

The two excluded Soviets were Dr V.K. Dobrosel'skii and Mr A.A. Kokoshin. Dobrosel'skii is, ironically a member of ICSU's standing committee on the free circulation of scientists. He is also widely rumoured to hold the rank of brigadier in the KGB (the Soviet secret police) and has previously been denied entry to other Western countries. Soviet delegates, insisted however, that Dobrosel'skii has several "outstanding", inventions to his credit. There was more puzzlement over the exclusion of Kokoshin, who is a member of ICSU's committee on science and technology in developing countries.

Most found the exclusions surprising and regrettable. There is no obvious rationale for a political reprisal by the newly elected Canadian Government, and some observers from Western nations believe Dobrosel'skii has genuinely worked for free movement of scientists regardless of what other positions he may hold. Everyone recognizes a grey area - ICSU has never consisted solely of active research scientists - and, as one US delegate observed, "we've some good scientists in the CIA" (Central Intelligence Agency). The assembly passed a resolution expressing its "deep concern" that entry visas were still being denied to scientists attending international meetings, singling out the governments of India, the Soviet Union and Canada. ICSU-sponsored activities will not be held in these countries until solutions have been found.

Visa problems also explain the Indian National Science Academy's decision to withdraw its offer to host the next ICSU general assembly; it has apparently been unable to secure the guarantee required by ICSU that scientists would be allowed entry visas. The 1986 general assembly will instead be held in Switzerland, but India may still be the host in 1988. Tim Beardsley
Drugs in athletics Mortality of
Soviet athletes

SUSPICIONS that the Soviet Union, and possibly some other socialist-bloc countries, routinely use anabolic steroids and other biochemicals in the training of athletes have now been fanned by an underground report which reached the West at the end of July, just in time for the Los Angeles Olympic Games. The report lists the names of 59 former Soviet Olympic competitors (including 26 medallists) from the 1952 games onwards, who have since died. The list, it is claimed, was compiled with the participation of Soviet athletes, many of whom fear for their own lifeexpectancy as a result of training procedures.

Although the list includes a few cases of

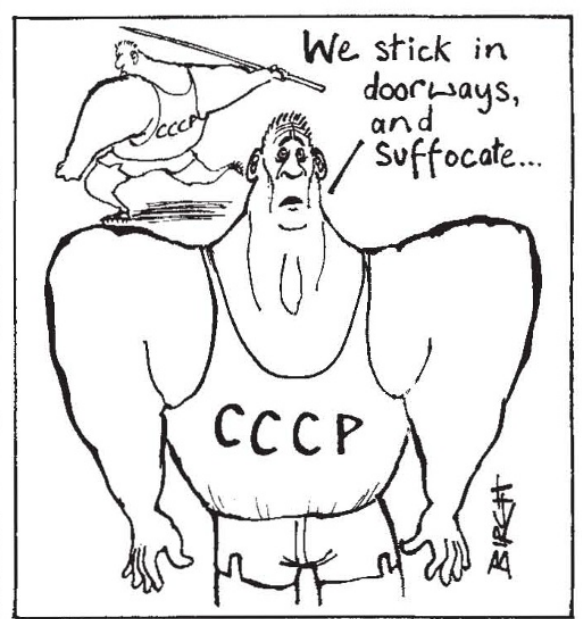

accidental death not related to sports, the overall figures show a death rate of 17.1 per thousand competitors, whereas the corresponding figure for the United States over the same period is 4.5 per 1,000 and for the United Kingdom 2.1 per 1,000. Deaths occurred most frequently in the 41-50 age group (18), 31-40 (11) and under 30 (9). The death rate, according to these figures, has more than doubled since 1976 , while remaining stable or even decreasing elsewhere.

The conclusion that these figures are related in some way to specifically Soviet training practices has been challenged by Michael Kessis, a physical education instructor in California who edits the Soviet Sports Review (a collection of translations from the Soviet sports press), but not, so far, by the Soviets themselves.

Thus, in a comment on "anti-Soviet" attitude in Los Angeles, Literaturnaya Gazeta did not deny the deaths but merely pointed out that Vsevolod Bobrov, the hockey-player, had been "approaching 60 ' when he died (he was in fact 57) and that Valerii Kharlamov (another hockeyplayer) and Valerii Popenchenko (a boxer) had died in "tragic accidents".

Apart from accidental victims, the 